\title{
FORMS OF DESTRUCTIVE RELATIONSHIPS AMONG THE EMPLOYEES: HOW MANY ARE THERE AND WHAT IS THE EXTENT OF THE SPREAD?
}

\author{
Jolita Vveinhardt \\ Vytautas Magnus University, Lithuania \\ E-mail: jolita.vveinhardt@gmail.com \\ Jūratė Kuklytė \\ Vytautas Magnus University, Lithuania \\ E-mail: jurate.kuklyte@gmail.com
}

Submission: 31/08/2016

Accept: 01/09/2016

\section{ABSTRACT}

The article presents various forms of destructive behaviour of employees, briefly introducing their key features. The main idea of this article is to carry out a comparative analysis of studies after discussing the forms of destructive behaviour of employees. Results of quantitative and qualitative research published in 2006-2016 have been compared. Results of studies of destructive relationships between employees in the work environment of organizations providing public services have been reviewed.

Keywords: destructive behaviour of employees, forms of destructive behaviour of employees, mobbing, single cases of harassment, discrimination, nepotism, favouritism, cronyism, social ostracism, organizational cynicism, deviant behaviour, informal social networks, public service 
INDEPENDENT JOURNAL OF MANAGEMENT \& PRODUCTION (IJM\&P)

http://www.ijmp.jor.br

v. 8, n. 1, January - March 2017

ISSN: 2236-269X

DOI: $10.14807 /$ ijmp.v8i1.532

\section{INTRODUCTION}

Relevance of research. Phenomena of destructive behaviour of employees breach functionality of relationships between employees and have a negative effect on the overall climate of the organization and quality of work.

Studies of destructive relationships of employees carried out at the global level support the effect of the phenomenon by psychological, social and economic costs (AKELLA, 2016; ALIAS; RASDI, 2015; HOLLIS, 2015; YILDIZ; LÜTFIHAK, 2015; HUTCHINSON; JACKSON, 2014; QURESHI et al., 2014; VEGA; COMER, 2005; BENNETT; ROBINSON, 2000).

Several forms of destructive relationships of employees that have received the maximum attention from the researchers are distinguished in the scientific literature. They are mobbing (AKELLA, 2016; PILCH; TURSKA, 2015; ŽUKAUSKAS; VVEINHARDT, 2015; VVEINHARDT, 2012a), discrimination (VASCONCELOS, 2015; VVEINHARDT et al., 2014; ROSENBAUM et al., 2012), nepotism (FU, 2015; ŽULOVA, 2015; JASKIEWICZ et al., 2013; KRAGH, 2012; ARASLI; TUMER, 2008), favouritism (PUČĖTAITÉ, 2016; PUČĖTAITE்; LÄMSÄ, 2008; ARASLI; TUMER, 2008; HIPPEL, 2008), cronyism (HOLLIBAUGH, 2015; KELEŞ et al., 2011), social ostracism (WU et al., 2016; VVEINHARDT, 2016; ZIMMERMAN et al., 2016; KULKARNI; SOMMER, 2015; O'REILLY et al., 2014; YAN et al., 2014) and social loafing (RECARIO et al., 2015; KARADAL; SAIGIN, 2013; VICKERY, 2013; MEFOK; NWANOSIKE, 2012).

However, in spite of the processes of globalisation and scientific contribution of researchers to the development of research of destructive employees' behaviour, there is a lack of comprehensive research works in the sphere of social services. The studies of destructive behaviour of employees published over the recent decade are more often in work environment of universities, their context is traditionally associated with undergraduate, post-graduate or doctoral study process.

Research problem. In scientific articles deviant behaviour in the work environment is noticed and more broadly studied in the public sector (BUUNK et al., 2016; HUTCHINSON, JACKSON, 2014; MCKAY, 2014; LIU et al., 2010), however, some research in the private sector is found as well (HOLIS, 2015; SALIN, 2003). The number of studies on destructive behaviour of employees is sufficient, but socio- 
cultural context, affecting the activities of political, administrative system of a country is focussed more often, therefore, it is appropriate to carry out a detailed analysis of scientific literature and to compare the results of studies carried out in different sectors of social services. It is also important to define clearly the mentioned forms of destructive behaviour of employees, highlighting their specific character. The following problem questions are raised in this research:

(1) what are the most common forms of destructive behaviour of employees analyzed in the scientific sources?

(2) what are the fundamental results of quantitative research of destructive behaviour of employees published over the last ten years?

(3) what are the fundamental results of qualitative research of destructive behaviour of employees published over the last ten years?

(4) what are the studies of destructive behaviour of employees carried out in the work environment of organizations providing public services?

Research subject: forms of destructive behaviour of employees.

The aim of the research is to carry out the comparative analysis of quantitative and qualitative research of the phenomena in order to emphasize the spread of the phenomena in the work environment of organizations providing public services after discussing the forms of destructive behaviour of employees.

The main research objectives are:

(1) to discuss the most common forms of destructive behaviour of employees analysed in scientific sources.

(2) to compare the results of quantitative research of destructive behaviour of employees published in 2006-2016.

(3) to compare the results of qualitative research of destructive behaviour of employees published in 2006-2016.

(4) to review the results of research of destructive behaviour of employees in the work environment of organizations providing public services.

Methods of research: analysis and synthesis of scientific literature, analysis of secondary data, content analysis. 
INDEPENDENT JOURNAL OF MANAGEMENT \& PRODUCTION (IJM\&P)

http://www.ijmp.jor.br

v. 8, n. 1, January - March 2017

ISSN: 2236-269X

DOI: 10.14807/ijmp.v8i1.532

\section{LITERATURE REVIEW}

Forms of destructive behaviour of employees. Starting from LEYMANN, a number of researchers explored the phenomenon of mobbing (LEYMANN, 1990; 1993, 1995, 1996; BJÖRKQVIST; ÖSTERMAN et al., 1994a, 1994b; ZUSCHLAG, 1994; NEUBERGER, 1994; DIERGARTEN, 1994; KNORZ; ZAPF, 1995; NIEDL, 1995; EINARSEN; SKOGSTAD, 1996; VARTIA-VAANANEN, 1996; EINARSEN; RAKNES, 1997; RAYNER; HOEL, 1997; QUINE, 1999). Many of these scientists have researched mobbing in various aspects: H. Leymann (1990) discussed it as psychological terror at work, K. Björkqvist, K. Österman and colleagues (1994b) as aggression among employees of the university and hidden gender aggression, $\mathrm{B}$. Zuschlag (1994) as harassment and bullying, O. Neuberger (1994) analysed mobbing as "playing bad games" in organizations, M. Vartia-Vaananen (1996) analysed the relationship of mobbing and organizational climate, etc. Mobbing is identified as a long-term, purposeful pressure, intimidation using psychological measures. Characteristics of mobbing are defined by psychological pressure, group participation, long-term, purposeful action. Most researchers emphasize that to detect and recognize such negative phenomena as the cases of harassment, they should be repetitive (EINARSEN; SKOGSTAD, 1996; VARTIA-VAANANEN, 1996; HOEL et al., 2003; SALIN, 2005). H. Leymann (1993) describes mobbing as negative behaviour that lasts for at least half a year, and is repeated at least once a week. This definition is perhaps the best to reflect the aims of the attacker - to create the environment full of permanent fear and threat to the victim.

Nepotism in the work environment can be of two forms (PADGETT; MORRIS, 2005): cross-generational nepotism and paired employees (Table 1). Crossgenerational nepotism is based on employment of members of the family (two or more generations), and it usually happens in family-owned companies that relatives or grandchildren are employed. The term "paired employees" is related to the relationship between the husband and wife at work. This form is seen as more controversial in the world of business taking into account the increasing occurrence of the phenomenon, when one of the spouses applies for a position in the same organization where the partner works without knowing this. There are very common conflicts between the partners, who work in the same organization and their relations become strictly subordinated (PADGETT; MORRIS, 2005). 
It is also important to review the variants of nepotism: favouritism and cronyism. On the basis of I-Pang Fu (2015), favouritism as well as nepotism and cronyism is identified with deviant behaviour in the business world, based on merit. Since these phenomena are associated with offences and defiance of individual or group norms, the analysis must take into account ethical principles - fairness, critique, supervision and profession (SHAPIRO; STEFKOVICH, 2011). According to Ozler et al. (2011), favouritism means preference for those who are more efficient and competent in individual participation in the labour processes. Favouritism is common in organizations. Ponzo and Scoppa (2010) distinguished group favouritism, which reduces the cost of recruitment. Nadeem et al. (2015) emphasize the positive effect of this phenomenon on the productivity. J. Vveinhardt and L. Petrauskaitè (2013) highlight the genetic context of kinship, characteristic of nepotism, which is uncharacteristic of phenomena of favouritism and protectionism. Favouritism is associated with emotional content - it can occur as benevolence in the absence of any direct or indirect tangible benefit, and protectionism is associated with systematic pursuit of benefit by illegal measures.

Table 1: The most frequently analysed forms of destructive behaviour of employees

\begin{tabular}{|c|c|c|}
\hline Title & Concept & Authors (year) \\
\hline Mobbing & $\begin{array}{l}\text { Direct or indirect aggression in the workplace by } \\
\text { one or more employees exercised } \\
\text { systematically and for a longer period of time, in } \\
\text { the situation where a person suffering from it is } \\
\text { experiencing difficulty in defending himself }\end{array}$ & 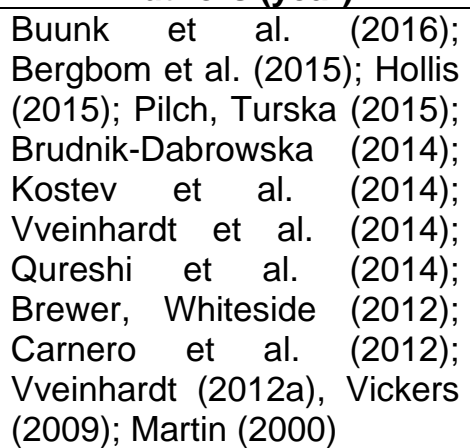 \\
\hline $\begin{array}{c}\text { Single cases of } \\
\text { harassment }\end{array}$ & $\begin{array}{l}\text { Actions, having the goal to cause mental (and } \\
\text { sometimes physical) pain. These actions are } \\
\text { directed against one or more persons. Duration } \\
\text { and frequency of the actions are not defined. }\end{array}$ & $\begin{array}{l}\text { Akella (2016); Cheung et al. } \\
\text { (2016); Hutchinson, Jackson } \\
\text { (2014); McKay (2014), } \\
\text { Bowen et al. (2011) }\end{array}$ \\
\hline Discrimination & $\begin{array}{l}\text { Restriction of a person's rights or the provision } \\
\text { of certain privileges with regard to the features } \\
\text { of gender, age, race, nationality, language, } \\
\text { origin, social position, religion, beliefs in the } \\
\text { work environment. }\end{array}$ & 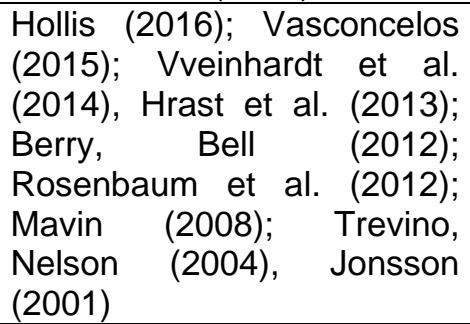 \\
\hline Nepotism & Illegal form of patronage, based on family ties. & 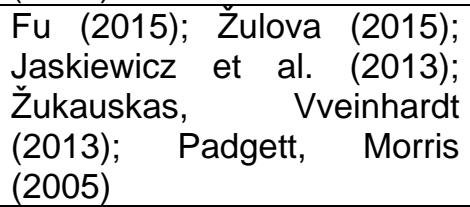 \\
\hline
\end{tabular}




\begin{tabular}{|c|c|c|}
\hline & $\begin{array}{l}\text { The problem of business ethics, where work } \\
\text { relationships are based on criteria of fellowship, } \\
\text { kinship. }\end{array}$ & $\begin{array}{l}\text { Pučètaitè (2016), Vveinhardt } \\
\text { (2012b); D‘Cruz, Noronha, } \\
\text { (2011); Palidauskaitè (2011); } \\
\text { Vosyliūtè (2010); Pučètaitè } \\
\text { et al. (2010); Ralys (2010); } \\
\text { Pruskus (2003) }\end{array}$ \\
\hline & $\begin{array}{l}\text { Nepotism is discrimination as well as exclusion } \\
\text { by gender or belonging to an ethnic group, only } \\
\text { in this case the discrimination is related to the } \\
\text { family, money, interest group and benefit. }\end{array}$ & $\begin{array}{l}\text { Kang, Kim (2016); Sarpong, } \\
\text { Maclean (2015); Vveinhardt, } \\
\text { Petrauskaite (2013); Arasli et } \\
\text { al. (2006); Mutlu (2000) }\end{array}$ \\
\hline & $\begin{array}{l}\text { The concept is used in parallel with bribery, } \\
\text { protectionism, corruption, tax evasion, electoral } \\
\text { bribery. }\end{array}$ & $\begin{array}{ll}\text { Yanga, Amoako } & (2013) ; \\
\text { Vveinhardt } & (2012 b) ; \\
\text { Piliponytė (2004) } & \end{array}$ \\
\hline & Manipulation in staff competitions. & $\begin{array}{l}\text { Onoshchenko, Williams } \\
\text { (2014); Yanga, Amoako } \\
\text { (2013); Pivoras (2012) }\end{array}$ \\
\hline \multirow[t]{2}{*}{ Favouritism } & $\begin{array}{l}\text { Preference to the persons who are more } \\
\text { efficient and competent in individual participation } \\
\text { in the work process. }\end{array}$ & $\begin{array}{l}\text { Fu (2015); Nadeem et al. } \\
\text { (2015); Ozler et al. (2011); } \\
\text { Ponzo, Scoppa (2010); } \\
\text { Arasli, Tumer (2008) }\end{array}$ \\
\hline & $\begin{array}{l}\text { Favourable behaviour of the heads of the } \\
\text { organization with the employees with whom they } \\
\text { have friendly relationships, regardless of their } \\
\text { productivity, effort and motivation. }\end{array}$ & $\begin{array}{l}\text { Pučètaitė (2016), Pučètaitè, } \\
\text { Lämsä (2008) }\end{array}$ \\
\hline Cronyism & $\begin{array}{l}\text { Granting high positions, honorary names to } \\
\text { friends, often occurring in the public service. }\end{array}$ & $\begin{array}{l}\text { Pučètaitè } \\
\text { Vasiljevienè (2006), Trevino, } \\
\text { Nelson (2004) }\end{array}$ \\
\hline $\begin{array}{l}\text { Nepotism } \\
\text { favouritism } \\
\text { cronyism }\end{array}$ & $\begin{array}{l}\text { Patronage in both the public and private sectors, } \\
\text { providing exclusively preferential treatment for } \\
\text { representatives of a certain social network. }\end{array}$ & $\begin{array}{l}\text { Safina (2015); Vveinhardt, } \\
\text { Zygmantaitè (2015); Arasli, } \\
\text { Tumer (2008) }\end{array}$ \\
\hline \multirow[t]{3}{*}{ Social ostracism } & $\begin{array}{l}\text { Social exclusion because of the individual } \\
\text { characteristics, attitudes in the work } \\
\text { environment. }\end{array}$ & $\begin{array}{l}\text { Gkorezis, Bellou (2016); Mok } \\
\text { et al. (2016); Wu et al. } \\
\text { (2016); Vveinhardt (2016); } \\
\text { Zimmerman et al. (2016); } \\
\text { Kulkarni, Sommer (2015); } \\
\text { Scott et al. (2015); Gamian- } \\
\text { Wilk (2013); Leung et al. } \\
\text { (2011); Ferris et al. (2008); } \\
\text { Kerr et al. (2008), Hitlan et } \\
\text { al. (2006) }\end{array}$ \\
\hline & $\begin{array}{l}\text { This is ignoring one or more persons or } \\
\text { exclusion from a group of individuals, which is } \\
\text { difficult to identify as it appears as punishment } \\
\text { for an individual's behaviour or aggression. }\end{array}$ & $\begin{array}{l}\text { Ogurlu (2015), Thau et al. } \\
\text { (2015); Sealey (2015); Scott } \\
\text { et al. (2014); Renn et al. } \\
\text { (2013); Nezlek et al. (2012); }\end{array}$ \\
\hline & $\begin{array}{l}\text { It can also be seen as intentional social isolation } \\
\text { planned in advance in order to cause negative } \\
\text { emotions, reducing the individual's self-esteem. }\end{array}$ & $\begin{array}{l}\text { O'Reilly et al. (2014); Cullen } \\
\text { et al. (2014); Yan et al. } \\
\text { (2014); Poon, Chen (2014); } \\
\text { Zhao et al. (2013); } \\
\text { Tambulasi (2009) }\end{array}$ \\
\hline \multirow[t]{2}{*}{$\begin{array}{l}\text { Social loafing } \\
\text { Other } \\
\text { phenomena } \\
\text { defining } \\
\text { destructive } \\
\text { relationships of } \\
\text { employees }\end{array}$} & $\begin{array}{l}\text { This is a phenomenon characteristic of persons } \\
\text { working a group, when they make less effort to } \\
\text { perform a task, and the result depends on the } \\
\text { joint efforts of members of the group and the } \\
\text { sum of the contributions. }\end{array}$ & $\begin{array}{lrr}\text { Recario } & \text { et al. } & \text { (2015); } \\
\text { Karadal, } & \text { Saigin } & \text { (2013); } \\
\text { Vickery (2013), Mefok, } & \text { Mefory } \\
\text { Nwanosike (2012), Van Dick } \\
\text { et al. (2009); Liden et al. } \\
\text { (2004); Tata (2002); Williams } \\
\text { et al. (1981) }\end{array}$ \\
\hline & $\begin{array}{l}\text { Organizational cynicism is a negative attitude, } \\
\text { which consists of the belief to make an influence } \\
\text { on the behaviour of other individuals, with a view } \\
\text { to united, better work in the organization. }\end{array}$ & Togonz, Yilmaz (2008) \\
\hline
\end{tabular}




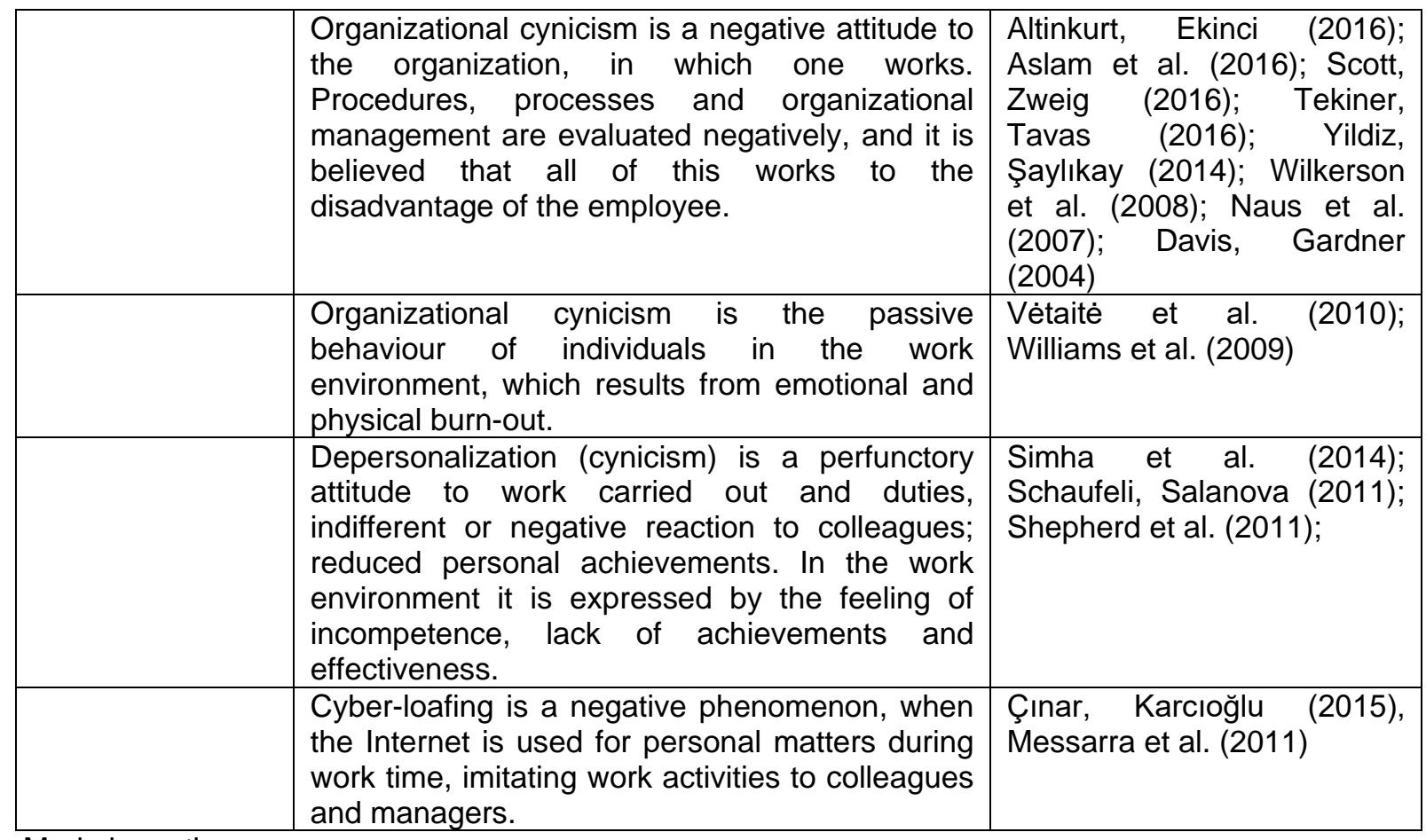

Made by authors

\section{QUANTITATIVE METHODS AND RESEARCHES}

In order to determine what instruments are used to research the forms of destructive behaviour of employees, analysis of scientific publications, which present the results of quantitative studies, was carried out (Table 2). The latest scientific publications in the journals, referred in Thomson Reuters Web of Knowledge and (or) Scopus and other databases were analysed. Taking into account the recent studies, the forms of destructive behaviour of employees are supplemented by religious and gender discrimination, and cyber-loafing. After completion of the initial review, it should be stated that most studies were carried out to investigate the destructive relationships between teenagers, but deviant behaviour occurs and is researched in various sectors (science and education, health care, transport, telecommunications, etc.).

Table 2. Destructive behaviour of employees: quantitative studies of 2006-2016

\begin{tabular}{|c|c|c|c|c|}
\hline Forms & Sample & Results of the research & Authors & $\begin{array}{c}\text { Year } \\
\text { of } \\
\text { publishina }\end{array}$ \\
\hline Mobbing & $\begin{array}{l}\mathrm{N}=2625 \\
\text { (patients of a } \\
\text { psychiatric } \\
\text { hospital, who } \\
\text { experienced } \\
\text { mobbing in }\end{array}$ & $\begin{array}{l}\text { Most persons who experienced mobbing } \\
\text { suffered from depression }(32.7 \%) \text {, and sleep } \\
\text { disorders }(20.4 \%) \text {. } 11.9 \% \text { of persons also } \\
\text { suffered from digestive system disorders, in } \\
9.7 \% \text { of the persons anxiety occurred. }\end{array}$ & $\begin{array}{l}\text { Kostev, K., } \\
\text { Rex, J., } \\
\text { Waehlert, } \\
\text { L., Hog. } \\
\text { D., } \\
\text { Heilmaier, }\end{array}$ & 2014 \\
\hline
\end{tabular}


INDEPENDENT JOURNAL OF MANAGEMENT \& PRODUCTION (IJM\&P)

http://www.ijmp.jor.br

v. 8, n. 1, January - March 2017

ISSN: 2236-269X

DOI: 10.14807/ijmp.v8i1.532

\begin{tabular}{|c|c|c|c|c|}
\hline Forms & Sample & Results of the research & Authors & $\begin{array}{c}\text { Year } \\
\text { of } \\
\text { publishing }\end{array}$ \\
\hline & $\begin{array}{l}2003-2012 \text { in } \\
\text { Germany) }\end{array}$ & & C. & \\
\hline & $\begin{array}{l}\mathrm{N}=207 \\
\text { (employees of } \\
\text { restaurants in } \\
\text { Norway) }\end{array}$ & $\begin{array}{l}\text { Regression model includes the team level } \\
\text { (climate factors) and the individual level } \\
\text { (personality traits). Statistical significance is } \\
\text { found only with long-term bullying. }\end{array}$ & $\begin{array}{l}\text { Mathisen, } \\
\text { G. E., } \\
\text { Ogaard, } \\
\text { T., } \\
\text { Einarsen, } \\
\text { S. }\end{array}$ & 2012 \\
\hline \multirow[t]{3}{*}{$\begin{array}{l}\text { Single } \\
\text { cases } \\
\text { of } \\
\text { harassment }\end{array}$} & $\begin{array}{l}\mathrm{N}=1313 \\
\text { (transport } \\
\text { sector } \\
\text { employees in } \\
\text { Poland) }\end{array}$ & $\begin{array}{l}\text { It was found that women were usually more } \\
\text { exposed to bullying than men ( } z=-1.999 ; p \\
<0.05) \text {. Women suffer more bullying than } \\
\text { men from colleagues in the workplace }(z=- \\
2.712 ; p<0.01) \text {, firstly: most bullying from } \\
\text { colleagues, which does harm to the image of } \\
\text { the employee }(z=-2.922 ; p<0.01) \text { and } \\
\text { bullying, which has a negative effect on } \\
\text { social relationships }(Z=-3.004 ; p<0.01) \text {. } \\
\text { Individuals with management experience are } \\
\text { bullied more often ( } z=-2.762 ; p<0.01) \text {. } \\
\text { Managing persons are bullied more often } \\
\text { than individuals with lower-ranking positions } \\
(Z=-2.260 ; p<0.05) \text {. }\end{array}$ & $\begin{array}{l}\text { Drabek, } \\
\text { M., } \\
\text { Merecz, D. }\end{array}$ & 2013 \\
\hline & $\begin{array}{l}\mathrm{N}=3112 \\
\text { (employees of } \\
25 \text { different } \\
\text { companies in } \\
\text { Italy) }\end{array}$ & $\begin{array}{l}50.9 \% \text { of men (10-18 years old) have more } \\
\text { often experienced single cases of } \\
\text { harassment in the Internet than in the real- } \\
\text { world communication. } 14.5 \% \text { of the } \\
\text { employees have experienced bullying in } \\
\text { work environment, and } 85.5 \% \text { employees } \\
\text { have never experienced bullying from their } \\
\text { colleagues or employers. }\end{array}$ & $\begin{array}{l}\text { Giorgi, G., } \\
\text { Arenas, } \\
\text { A., Leon- } \\
\text { Perez, J. } \\
\text { M. }\end{array}$ & 2011 \\
\hline & $\begin{array}{l}\mathrm{N}=432 \\
\text { (schoolchildren } \\
\text { of the } 8^{\text {th }} \text { grade) }\end{array}$ & $\begin{array}{l}\text { It was found that } 67 \% \text { of the respondents } \\
\text { were called "nerds" because of their } \\
\text { appearance or abilities. } 46 \% \text { of the } \\
\text { respondents experienced at least one of the } \\
13 \text { forms of bullying (calling names, bullying, } \\
\text { threats, pushing, dropping books from the } \\
\text { desk, fighting, etc.) when learning in the } 6^{\text {th }} \\
\text { grade. Such bullying was most frequently } \\
\text { experienced by boys. }\end{array}$ & $\begin{array}{l}\text { Peterson } \\
\text { J. S., Ray } \\
\text { K. E. }\end{array}$ & 2006 \\
\hline $\begin{array}{c}\text { Religious } \\
\text { discriminatio } \\
n\end{array}$ & $\begin{array}{l}\mathrm{N}=80 \\
\text { (persons of } \\
\text { Rastafari } \\
\text { religion in } \\
\text { South Africa) }\end{array}$ & $\begin{array}{l}41.5 \% \text { of the persons who have a feeling of } \\
\text { commitment to the employer have } \\
\text { experienced discrimination. }\end{array}$ & $\begin{array}{l}\text { Van der } \\
\text { Walt, F., } \\
\text { Mpholo, T. } \\
\text { S., Jonck, } \\
\text { P. }\end{array}$ & 2016 \\
\hline $\begin{array}{c}\text { Gender } \\
\text { discriminatio } \\
n\end{array}$ & $\begin{array}{l}\mathrm{N}=362 \\
\text { (employees in } \\
\text { China) }\end{array}$ & $\begin{array}{l}\text { It was found that gender and gender } \\
\text { comparison fully mediated the relationship } \\
\text { between strength of gender identification } \\
\text { and perceived gender discrimination. The } \\
\text { authors also found that gender comparison } \\
\text { and perceived gender bias against women } \\
\text { partially mediated the relationship between } \\
\text { gender and perceived gender discrimination. }\end{array}$ & $\begin{array}{ll}\text { Foley, } & \text { S., } \\
\text { Ngo, } & \text { H., } \\
\text { Loi, } & \text { R., } \\
\text { Zheng, } & \text { X. }\end{array}$ & 2015 \\
\hline
\end{tabular}


INDEPENDENT JOURNAL OF MANAGEMENT \& PRODUCTION (IJM\&P)

http://www.ijmp.jor.br

v. 8, n. 1, January - March 2017

ISSN: 2236-269X

DOI: 10.14807/ijmp.v8i1.532

\begin{tabular}{|c|c|c|c|c|}
\hline Forms & Sample & Results of the research & Authors & $\begin{array}{c}\text { Year } \\
\text { of } \\
\text { publishing }\end{array}$ \\
\hline $\begin{array}{l}\text { Nepotism } \\
\text { favouritism } \\
\text { cronyism }\end{array}$ & $\begin{array}{l}\mathrm{N}=440 \\
\text { (telecommunica } \\
\text { tions sector } \\
\text { employees in } \\
\text { Pakistan) }\end{array}$ & $\begin{array}{l}\text { Nepotism, favouritism, and cronyism are } \\
\text { directly related to the job satisfaction in the } \\
\text { telecommunications sector in Pakistan and } \\
\text { have a positive effect on productivity. }\end{array}$ & $\begin{array}{l}\text { Nadeem, } \\
\text { M., } \\
\text { Ahmad, } \\
\text { R., } \\
\text { Ahmad, } \\
\text { N., Batool, } \\
\text { S., R., } \\
\text { Shafique, } \\
\text { N. }\end{array}$ & 2015 \\
\hline \multirow[t]{3}{*}{$\begin{array}{c}\text { Social } \\
\text { ostracism }\end{array}$} & $\begin{array}{l}\mathrm{N}=244 \\
\text { (secondary } \\
\text { school students } \\
\text { evaluated using } \\
\text { Rosenberg self- } \\
\text { esteem scale) }\end{array}$ & $\begin{array}{l}\text { Self-esteem and perceived social } \\
\text { competence was negatively related with } \\
\text { ostracism and loneliness. In addition, } \\
\text { ostracism positively correlates with } \\
\text { loneliness. Ostracism also had a negative } \\
\text { impact on self-esteem. }\end{array}$ & $\begin{array}{l}\text { Cetintas, } \\
\text { K., } \\
\text { Saricam, } \\
\text { H. }\end{array}$ & 2016 \\
\hline & $\begin{array}{l}\mathrm{N}=94 \quad{ }^{2}-8^{\text {th }} \\
\text { grade students } \\
\text { with special } \\
\text { abilities, } \\
\text { attending a day } \\
\text { centre } \\
\text { Bakcilar, in } \\
\text { Istanbul, in } \\
\text { Turkey) }\end{array}$ & $\begin{array}{l}\text { It was found that there is a relationship } \\
\text { between high intelligence and social } \\
\text { ostracism. Ostracism increases with the } \\
\text { increasing level of intelligence. The cases of } \\
\text { social ostracism are more likely to occur in } \\
8^{\text {th }} \text { grade schoolchildren than in those } \\
\text { learning in the } 6^{\text {th }} \text { or } 7^{\text {th }} \text { grades. }\end{array}$ & Ogurlu, U. & 2015 \\
\hline & $\begin{array}{l}\mathrm{N}=376 \quad\left(9-12^{\text {th }}\right. \\
\text { grade } \text { students } \\
\text { in } \\
\text { India) }\end{array}$ & $\begin{array}{l}25 \% \text { of respondents experienced social } \\
\text { isolation within the last } 30 \text { days. It was found } \\
\text { that girls suffered from psychological } \\
\text { violence more often than boys. }\end{array}$ & Sullivan & 2006 \\
\hline $\begin{array}{l}\text { Social } \\
\text { loafing }\end{array}$ & $\begin{array}{l}\mathrm{N}=259 \quad \text { (girls, } \\
\text { handball } \\
\text { players in } \\
\text { Norway) }\end{array}$ & $\begin{array}{l}\text { Fairness is statistically significant when } \\
\text { compared to professionalism and statistically } \\
\text { insignificant compared to the team climate. } \\
\text { Professionalism correlated with the } \\
\text { commitment to the team and the expertise of } \\
\text { the team and task cohesion. Social loafing in } \\
\text { the team is statistically insignificant. }\end{array}$ & $\begin{array}{l}\text { De } \\
\text { Backer, M. } \\
\text { Boen, F., } \\
\text { De } \\
\text { Cuyper, } \\
\text { B., } \\
\text { Hoigard, } \\
\text { R., Vande } \\
\text { Broek, G. }\end{array}$ & 2015 \\
\hline $\begin{array}{l}\text { Cyber- } \\
\text { loafing }\end{array}$ & $\begin{array}{l}\mathrm{N}=360 \quad \text { (public } \\
\text { sector } \\
\text { employees in } \\
\text { Erzurum, } \\
\text { Turkey) }\end{array}$ & $\begin{array}{l}\text { It was found that there is no relation between } \\
\text { cyber-loafing and organizational civic } \\
\text { behaviour. The relationship between cyber- } \\
\text { loafing and demographic characteristics } \\
\text { (age, marital status, position) was found. }\end{array}$ & $\begin{array}{l}\text { Cinar, O., } \\
\text { Karcioglu, } \\
\text { F. }\end{array}$ & 2015 \\
\hline $\begin{array}{c}\text { Cyberbullyin } \\
g\end{array}$ & $\begin{array}{l}\mathrm{N}=19406 \quad(11- \\
16 \text { year old } \\
\text { teenagers in } \\
\text { Europe, } 50 \% \\
\text { girls), applying } \\
\text { SDQ-Strengths } \\
\text { and Difficulties } \\
\text { Questionnaire }\end{array}$ & $\begin{array}{l}\text { Multinomial logistic regression analysis } \\
\text { showed that compared with those who took } \\
\text { part in initiation of electronic harassment } \\
\text { online, but view the web content related to } \\
\text { suicide, it was more frequent for victims of } \\
\text { bullying, rather than for bullies. Viewing of } \\
\text { web content related to self-harm was higher } \\
\text { for all cyberbullying roles, in particular for } \\
\text { cyberbully-victims. In addition, investigating } \\
\text { the relationship between cyberbullying roles } \\
\text { and viewing suicide-related content online, } \\
\text { statistical insignificance in respect of } \\
\text { psychological problems was found. }\end{array}$ & Görzig, A. & 2016 \\
\hline
\end{tabular}




\section{QUALITATIVE METHODS AND RESEARCHES}

Empirical research is revealed in the paradigm of social constructivism. These are the basic philosophical attitudes, which a qualitative study is based on. Social constructivism enables to know the reality perceived by the individuals and groups through its common development (BROWN; BAKER, 2007; BERGER; LUCKMAN, 1999) - how a social phenomenon is formulated and institutionalized. According to the paradigm of social constructivism, individuals themselves construct through interactions with each other common meanings, used in the work environment, interpreting the elements of their social and cultural life. However, this does not mean that individuals always have the unanimous agreement on each situation. There are a lot of subjective and contradictory perceptions based on certain validity, competing in social or deviant situations. Therefore, the critical role in the paradigm of social constructivism falls to the language presented with the help of discourse: verbal language, written text, socially understandable gestures, which are then reflected in the sequence of behaviours. They are directed to a specific goal, focused on the changes, which means that individuals must agree on certain values and tolerate it. The qualitative studies of the latter decade are reviewed in Table 3.

Table 3. Destructive behaviour of employees: qualitative studies of 2011-2016

\begin{tabular}{|c|c|c|c|c|}
\hline Forms & Sample & Results of the research & Authors & $\begin{array}{l}\text { Year } \\
\text { of } \\
\text { publishing }\end{array}$ \\
\hline \multirow{3}{*}{ Mobbing } & $\begin{array}{l}\mathrm{N}=161 \text { (university } \\
\text { students) }\end{array}$ & $\begin{array}{l}\text { Continuation responsibility } \\
\text { and autonomy among the } \\
\text { victim of mobbing and } \\
\text { bystanders are directly } \\
\text { related. Females, helping the } \\
\text { victims of mobbing showed } \\
\text { sympathy and greater } \\
\text { willingness to help, and the } \\
\text { victims of mobbing elicited } \\
\text { less anger. }\end{array}$ & $\begin{array}{l}\text { Mulder, R., } \\
\text { Bos, } \quad \text { E., } \\
\text { Pouwelse, M., } \\
\text { van Dam, K. }\end{array}$ & 2016 \\
\hline & $\begin{array}{lr}\mathrm{N}=826 \quad \text { (private } \\
\text { and public sector } \\
\text { employees } \\
\text { Ankara) }\end{array}$ & $\begin{array}{l}\text { Mobbing directly influences } \\
\text { stress at work and causes the } \\
\text { burnout syndrome. }\end{array}$ & $\begin{array}{l}\text { Erol, Y., } \\
\text { Oztoprak, M. } \\
\text { T. }\end{array}$ & 2015 \\
\hline & $\begin{array}{l}\mathrm{N}=20 \text { (employees } \\
\text { of different sectors } \\
\text { who experienced } \\
\text { mobbing and } \\
\text { looked for help in } \\
\text { the help centre in } \\
\text { Turkey - 13 } \\
\text { persons, working }\end{array}$ & $\begin{array}{l}\text { Five aspects to overcome } \\
\text { mobbbing in work environment } \\
\text { have been identified: } \\
\text { avoidance, patience - } \\
\text { confrontation, threats to } \\
\text { personal health - applying for } \\
\text { help, despair - destructive } \\
\text { actions, surrender - leaving }\end{array}$ & Karatuna, I. & 2015 \\
\hline
\end{tabular}


INDEPENDENT JOURNAL OF MANAGEMENT \& PRODUCTION (IJM\&P)

http://www.ijmp.jor.br

v. 8, n. 1, January - March 2017

ISSN: 2236-269X

DOI: 10.14807/ijmp.v8i1.532

\begin{tabular}{|c|c|c|c|c|}
\hline \multirow[t]{3}{*}{ Forms } & Sample & \multirow[t]{2}{*}{ Results of the research } & \multirow[t]{2}{*}{ Authors } & \multirow[t]{2}{*}{$\begin{array}{c}\text { Year } \\
\text { of } \\
\text { publishing }\end{array}$} \\
\hline & $\begin{array}{l}\text { in the public } \\
\text { sector) }\end{array}$ & & & \\
\hline & $\begin{array}{l}\mathrm{N}=384 \quad \text { (banking } \\
\text { sector employees } \\
\text { in Turkey) }\end{array}$ & $\begin{array}{l}\text { It was found that } 32 \% \text { of } \\
\text { persons admitted the fact they } \\
\text { have become victims of } \\
\text { workplace mobbing, } 56 \% \text { said } \\
\text { they faced the expressions of } \\
\text { mobbing one or more times } \\
\text { during the work time in the } \\
\text { banking sector. } 66.9 \% \text { of } \\
\text { persons stated that the cases } \\
\text { of mobbing were initiated by } \\
\text { their manager. }\end{array}$ & Gok, S. & 2011 \\
\hline \multirow[b]{2}{*}{$\begin{array}{c}\text { Single cases } \\
\text { of } \\
\text { harassment }\end{array}$} & $\begin{array}{lr}\mathrm{N}=6299 & (8-18 \\
\text { year old persons } \\
\text { in } & \text { the } \\
\text { Netherlands) } & \end{array}$ & $\begin{array}{l}50.9 \% \text { of men (10-18 year old) } \\
\text { have more commonly } \\
\text { experienced single cases of } \\
\text { harassment online than in the } \\
\text { real communication. }\end{array}$ & $\begin{array}{l}\text { Kerstens, J., } \\
\text { Veenstra, S., } \\
\text { Jaishankar, K }\end{array}$ & 2015 \\
\hline & $\begin{array}{l}\mathrm{N}=7000 \quad(12-18 \\
\text { year old persons } \\
\text { in Turkey) }\end{array}$ & $\begin{array}{l}11 \% \text { of the participants stated } \\
\text { that they have experienced } \\
\text { single cases of harassment } \\
\text { and therefore felt humiliation, } \\
69 \% \text { said that bullying was } \\
\text { initiated by their friends or } \\
\text { colleagues. }\end{array}$ & $\begin{array}{l}\text { General } \\
\text { Directorate of } \\
\text { Family and } \\
\text { Community } \\
\text { Services }\end{array}$ & 2013 \\
\hline \multirow[t]{2}{*}{$\begin{array}{c}\text { Social } \\
\text { ostracism }\end{array}$} & $\begin{array}{l}\mathrm{N}=58 \\
\text { schoolchildren }\end{array}$ & $\begin{array}{l}\text { It was investigated whether } \\
\text { the persecution experience at } \\
\text { school is related with } \\
\text { ostracism in the virtual } \\
\text { environment of the Cyberball } \\
\text { game. Two groups have been } \\
\text { compared: } 26 \text { victims of } \\
\text { mobbing, and bu haven't } \\
\text { schoolchildren who (the } \\
\text { experienced bullying } \\
\text { average age 12.12). After the } \\
\text { Cyberball game, the condition } \\
\text { of ostracism in students who } \\
\text { have experienced bullying } \\
\text { occurred by significantly less } \\
\text { emotions on the meaningful } \\
\text { existence compared with the } \\
\text { students who haven't } \\
\text { experienced bullying. The } \\
\text { results show that the students, } \\
\text { who had suffered from } \\
\text { bullying before, are more } \\
\text { affected by the experience of } \\
\text { social exclusion than the } \\
\text { students who have not } \\
\text { experienced bullying or the } \\
\text { victim syndrome. }\end{array}$ & $\begin{array}{l}\text { Ruggieri, S., } \\
\text { Bendixen, M., } \\
\text { Gabriel, U., } \\
\text { Alsaker, F. }\end{array}$ & 2013 \\
\hline & $\begin{array}{l}\mathrm{N}=146 \text { (persons of } \\
\text { different age) }\end{array}$ & $\begin{array}{l}\text { Very high social ostracism } \\
\text { occurs in individuals with } \\
\text { Asperger's } \\
\text { because of communication or } \\
\text { clothing. Recommendations to }\end{array}$ & Richards, J. & 2012 \\
\hline
\end{tabular}


INDEPENDENT JOURNAL OF MANAGEMENT \& PRODUCTION (IJM\&P)

http://www.ijmp.jor.br

v. 8, n. 1, January - March 2017

ISSN: 2236-269X

DOI: 10.14807/ijmp.v8i1.532

\begin{tabular}{|c|c|c|c|c|}
\hline Forms & Sample & Results of the research & Authors & $\begin{array}{c}\text { Year } \\
\text { of } \\
\text { publishing }\end{array}$ \\
\hline & & $\begin{array}{l}\text { formalize the nature of work to } \\
\text { people with Asperger's } \\
\text { syndrome and to define the } \\
\text { norms of behaviour to reduce } \\
\text { social ostracism are provided. }\end{array}$ & & \\
\hline Social loafing & $\begin{array}{lr}\mathrm{N}=158 & \text { private and } \\
\text { public } & \text { sector } \\
\text { employees } & \text { in } \\
\text { Turkey) } & \end{array}$ & $\begin{array}{l}\text { Social loafing is not related to } \\
\text { perception of citizenship } \\
\text { (statistically insignificant). } \\
\text { Gender and marital status are } \\
\text { related to citizenship and } \\
\text { social loafing. }\end{array}$ & $\begin{array}{l}\text { Karadal, } \mathrm{H} . \\
\text { Saygin, M. }\end{array}$ & 2013 \\
\hline
\end{tabular}

Made by authors

\section{RESEARCH OF DESTRUCTIVE BEHAVIOUR OF EMPLOYEES IN THE WORK ENVIRONMENT OF PUBLIC SERVICE ORGANIZATIONS}

P. Drentea (1998), E. Boxman et al. (1991), J. H. Braddock and J. Mcpartland (1987) investigated the stress experienced because of promotion in informal social networks in accordance with neoclassical concept of economics in homogeneous labour markets. However, M. Granovetter (1974) argued that the persons who have found a job by informal methods in social networks have a better access to labour market information, due to higher income and status, higher job satisfaction occurs. Table 4 briefly provides an overview of the outcomes of destructive relationships between employees in the work environment of organizations providing public services.

Table 4. Destructive behaviour of employees in the work environment of public service organizations

\begin{tabular}{|c|c|c|c|c|c|}
\hline Phenomenon & Sample & Tool / method & Results of the research & Authors & $\begin{array}{c}\text { Year } \\
\text { of } \\
\text { publishing }\end{array}$ \\
\hline Mobbing & $\begin{array}{l}\mathrm{N}=30 \text { (social } \\
\text { workers, } \\
\text { psychologists } \\
\text {, therapists, } \\
\text { and others } \\
\text { working in the } \\
\text { children's } \\
\text { homes, } \\
\text { children's day } \\
\text { care centres } \\
\text { in the Czech } \\
\text { Republic) }\end{array}$ & Interview & $\begin{array}{l}\text { Most of the respondents (14\%) } \\
\text { said they experienced verbal } \\
\text { and psychological violence, } \\
\text { occurring in various forms - as } \\
\text { malicious rumours, backbiting, } \\
\text { offensive sexist jokes, } \\
\text { threatening swear-words. It } \\
\text { was found that long-term } \\
\text { verbal bullying is tolerated } \\
\text { because of the respondents' } \\
\text { old age and fear of losing their } \\
\text { job. Those persons who do } \\
\text { paperwork and do not provide } \\
\text { social services for children did } \\
\text { not become the victims of } \\
\text { mobbing. }\end{array}$ & $\begin{array}{l}\text { Zigman, } \\
\text { O. }\end{array}$ & 2014 \\
\hline
\end{tabular}


INDEPENDENT JOURNAL OF MANAGEMENT \& PRODUCTION (IJM\&P)

http://www.ijmp.jor.br

v. 8, n. 1, January - March 2017

ISSN: 2236-269X

DOI: 10.14807/ijmp.v8i1.532

\begin{tabular}{|c|c|c|c|c|c|}
\hline \multirow[t]{2}{*}{ Phenomenon } & Sample & Tool / method & Results of the research & Authors & $\begin{array}{c}\text { Year } \\
\text { of } \\
\text { publishina }\end{array}$ \\
\hline & $\begin{array}{l}\mathrm{N}=1775 \\
\text { (public sector } \\
\text { employees - } \\
\text { the } \\
\text { Confederatio } \\
\mathrm{n} \text { of } \\
\text { Norwegian } \\
\text { Enterprises } \\
\text { and the } \\
\text { Norwegian } \\
\text { Association of } \\
\text { Local and } \\
\text { Regional } \\
\text { Authorities I } \\
\text { the National } \\
\text { Insurance } \\
\text { Administratio } \\
\mathrm{n} \text { of } \\
\text { Norwegian } \\
\text { Government) }\end{array}$ & Questionnaire & $\begin{array}{l}\text { Partial support for Leymann's } \\
\text { assumption that long-term } \\
\text { bullying at work will lead to } \\
\text { social exclusion in the work } \\
\text { environment was found. } \\
\text { Logistic regressions showed } \\
\text { that victims of bullying changed } \\
\text { their work more often than } \\
\text { individuals who were not } \\
\text { bullied during the research. } \\
\text { The results of the research } \\
\text { also showed that victims of } \\
\text { bullying have left the work } \\
\text { more often than the persons } \\
\text { who have not experienced } \\
\text { long-term bullying. However, } \\
\text { most victims are still working } \\
\text { full time or part time two years } \\
\text { or later. }\end{array}$ & $\begin{array}{l}\text { Berthelse } \\
\text { n, M., } \\
\text { Skogstad } \\
\text {, Lau, B., } \\
\text { Einarsen, } \\
\text { S. }\end{array}$ & 2011 \\
\hline \multirow[t]{2}{*}{$\begin{array}{c}\text { Gender } \\
\text { discrimination }\end{array}$} & $\begin{array}{l}\mathrm{N}=80 \quad(23 \\
\text { women and } 7 \\
\text { men from } 12 \\
\text { different } \\
\text { academic } \\
\text { institutions) }\end{array}$ & Interview & $\begin{array}{l}\text { Results of the research } \\
\text { suggest that discrimination of } \\
\text { women in Lithuanian academic } \\
\text { institutions is prohibited, but it } \\
\text { exists. Women feel shame and } \\
\text { fear to submit evidence of } \\
\text { discrimination, is ignored. } \\
\text { discrimination is an } \\
\text { Standards and norms of } \\
\text { conduct are not clearly defined, } \\
\text { therefore, the respondents } \\
\text { believe that the complaints of } \\
\text { women are discriminated and } \\
\text { cause double dissatisfaction or } \\
\text { emotional outbreak. }\end{array}$ & $\begin{array}{c}\text { Vasiljevie } \\
\text { nè, N., } \\
\text { Pučètaitè } \\
\text {, R. }\end{array}$ & 2009 \\
\hline & $\begin{array}{l}\mathrm{N}=26 \text { (female } \\
\text { counsellors in } \\
\text { a sports club } \\
\text { in Russia) }\end{array}$ & Interview & $\begin{array}{l}\text { Discrimination of women based } \\
\text { on the age was found. The } \\
\text { standards for this profession } \\
\text { for the middle-age and middle- } \\
\text { class women to meet the } \\
\text { masculine standards of } \\
\text { physical capacity - "fit into a } \\
\text { glass slipper". }\end{array}$ & $\begin{array}{c}\text { Adamson } \\
\text {, M. }\end{array}$ & 2015 \\
\hline $\begin{array}{c}\text { Social } \\
\text { ostracism }\end{array}$ & $\mathrm{N}=191$ & Interview & $\begin{array}{l}\text { The results of the research } \\
\text { showed that the state } \\
\text { investment in involvement of } \\
\text { the stigmatized members of } \\
\text { the public in the labour market } \\
\text { and in the promotion of } \\
\text { socialization cannot be limited } \\
\text { to physical provision of the } \\
\text { place of work and adaptation of } \\
\text { the workplace to the individual } \\
\text { needs, while ignoring the } \\
\text { factors of psychological } \\
\text { comfort which depend on the } \\
\text { management culture of the }\end{array}$ & $\begin{array}{l}\text { Vveinhar } \\
\mathrm{dt}, \mathrm{J} \text {. }\end{array}$ & 2016 \\
\hline
\end{tabular}


INDEPENDENT JOURNAL OF MANAGEMENT \& PRODUCTION (IJM\&P)

http://www.ijmp.jor.br

v. 8, n. 1, January - March 2017

ISSN: 2236-269X

DOI: 10.14807/ijmp.v8i1.532

\begin{tabular}{|c|c|c|c|c|c|}
\hline Phenomenon & Sample & Tool / method & Results of the research & Authors & $\begin{array}{c}\text { Year } \\
\text { of } \\
\text { publishing }\end{array}$ \\
\hline & & & $\begin{array}{l}\text { organization. The formal status } \\
\text { of a social enterprise granted } \\
\text { by the state may be perceived } \\
\text { and is treated in practice of } \\
\text { activities of companies as a } \\
\text { specific business niche, } \\
\text { without forming the values of } \\
\text { the social enterprise, stemming } \\
\text { from the perception of social } \\
\text { responsibility. Formal } \\
\text { requirements of adaptation of } \\
\text { physical working environment } \\
\text { for persons with disabilities do } \\
\text { not solve and cannot solve the } \\
\text { issues of psychological safety } \\
\text { and indirect discrimination of } \\
\text { employees, and can cause } \\
\text { additional traumas resulting } \\
\text { from social exclusion and } \\
\text { psychological pressure in } \\
\text { emplovees' relationships. }\end{array}$ & & \\
\hline $\begin{array}{l}\text { Organizational } \\
\text { cynicism }\end{array}$ & $\begin{array}{l}\mathrm{N}=436 \\
\text { (teachers) }\end{array}$ & $\begin{array}{l}\text { Teachers' } \\
\text { Occupational } \\
\text { Professionalism } \\
\text { Scale and } \\
\text { Organizational } \\
\text { Cynicism Scale } \\
\text { used }\end{array}$ & $\begin{array}{l}\text { Professionalism of teachers' } \\
\text { work was high, and their } \\
\text { organizational cynicism was of } \\
\text { a medium level. Negative } \\
\text { relation between the } \\
\text { employees' professionalism } \\
\text { and their cognitive level was } \\
\text { identified. Affective cynicism } \\
\text { level was found. According to } \\
\text { regression analysis, only } \\
\text { contribution to the organization } \\
\text { as one of the four sub- } \\
\text { dimensions of professionalism } \\
\text { was a significant predictor of } \\
\text { cognitive and emotional } \\
\text { cynicism. }\end{array}$ & $\begin{array}{l}\text { Altinkurt, } \\
\text { Y., } \\
\text { Ekinci, R. }\end{array}$ & 2016 \\
\hline
\end{tabular}

Made by authors

\section{CONCLUSIONS}

Although the research of destructive behaviour of employees is quite segmented, three main areas can be distinguished. The first area includes the direct colleagues' violence, which is identified as mobbing, single cases of harassment, social ostracism, discrimination, organizational cynicism. The object of the second research area can be identified as the abuse of position by appropriating the resources of the organization or corruption and covers such aspects of the behaviour as nepotism, favouritism and cronyism. 
INDEPENDENT JOURNAL OF MANAGEMENT \& PRODUCTION (IJM\&P)

http://www.ijmp.jor.br

v. 8, n. 1, January - March 2017

ISSN: 2236-269X

DOI: 10.14807/ijmp.v8i1.532

The third area of research includes toadyism in organizations, occurring as social loafing and one of its forms - cyber-loafing. On the one hand, segmentation of research to narrow aspects allows exploring the phenomenon in more details, on the other hand, it does not give much value if we want to see the overall picture.

For example, the existence of mobbing, social ostracism and nepotism with its different ways of expression shows the existence of certain social networks, but there is a lack of research to evaluate relations of the general context of formation of such networks with the different forms of deviant behaviour.

Results of the research show that the forms of destructive relationships in the work environment have a negative impact on the physical and psychological health of employees, their productivity, motivation, job satisfaction, health, work and induce quitting a job. Although the relationship between the victims of negative behaviour and their gender has been highlighted, there is a lack of research to assess the relationship of negative behaviour in the young age with the negative behaviour in the older age, i.e. in the work environment. In addition, there is a lack of research, in which the negative behaviour would be studied in different areas of occupational activities using the same method of quantitative research.

Similarly, in the case of qualitative research the differences in methodological approach between the researchers that don't let compare findings of the studies and derive common regularities when analysing the causes, are highlighted. The above mentioned problems become apparent also when looking at the research of destructive relationships between employees in the sphere of social services, focussing on some of the most frequently researched areas does not help the possibility of optimal use of the results in the broad diversity of the sector.

Therefore, there is a relevant need for future studies that would cover a wider context of professional activities and cross-sectoral context, allowing outlining trajectories of different kinds of deviant behaviour in the work environment.

\section{REFERENCES}

ADAMSON, M. (2015) The making of a glass slipper: Exploring patterns of inclusion and exclusion in a feminized profession. Equality, Diversity and Inclusion: An International Journal, v. 34, n. 3, p. 214-226, http://dx.doi.org/10.1108/EDI-012014-0002 
AKELLA, D. (2016) Workplace Bullying: Not a Manager's Right? Journal of Workplace Rights, p. 1-10. DOI: 10.1177/2158244016629394

ALIAS, M.; RASDI, R. M. (2015) Organizational Predictors of Workplace Deviance Among Support Staff. Procedia - Social and Behavioral Sciences, v. 172, p. 126133. doi:10.1016/j.sbspro.2015.01.345

ALTINKURT, Y.; EKINCI, C. E. (2016) Examining the Relationships between Occupational Professionalism and Organizational Cynicism of Teachers.

Educational Process: International Journal, v. 5, n. 3, p. 236-253, http://dx.doi.org/10.12973/edupij.2016.53.5

ARASLI, H.; BAVIK, A.; EKIZ, E. H. (2006) The effects of nepotism on human resource management: The case of three, four and five star hotels in Northern Cyprus. International Journal of Sociology and Social Policy, v. 26, n. 7/8, p. 295-308, http://dx.doi.org/10.1108/01443330610680399

ARASLI, H.; TUMER, M. (2008) Nepotism, Favoritism and Cronyism: A Study of their Effects on Job Stress and Job Satisfaction in the Banking Industry of North Cyprus. Social Behavior and Personlity, v. 36, n. 9, p. 1237-1250.

ASLAM, U.; ILYAS, M.; IMRAN, M. K. (2016) Detrimental effects of cynicism on organizational change: An interactive model of organizational cynicism (a study of employees in public sector organizations). Journal of Organizational Change Management, v. 29, n. 4, p. 580-598, http://dx.doi.org/10.1108/JOCM-12-2014-0231 BENNETT, R. J.; ROBINSON, S. L. (2000) Development of a measure of workplace deviance. Journal of Applied Psychology, v. 85, n. 3, p. 349-360.

BERGBOM, B.; VARTIA-VAANANEN, M.; KINNUNEN, U. (2015) Immigrants and natives at work: exposure to workplace bullying. Employee Relations, v. 37, n. 2, p. 158-175, http://dx.doi.org/10.1108/ER-09-2014-0101

BERGER, P. L.; LUCKMAN, T. (1999) Socialinès tikrovès konstravimas: žinojimo sociologijos traktatas. Vilnius: Pradai.

BERRY, D.; BELL, M. P. (2012) Inequality in organizations: stereotyping, discrimination, and labor law exclusions. Equality, Diversity and Inclusion: An International Journal, v. 31, n. 3, p. 236-248, http://dx.doi.org/10.1108/02610151211209090

BERTHELSEN, M.; SKOGSTAD, A.; LAU, B.; EINARSEN, S. (2011) Do they stay or do they go?: A longitudinal study of intentions to leave and exclusion from working life among targets of workplace bullying. International Journal of Manpower, v. 32, n. 2, p. 178-193, http://dx.doi.org/10.1108/01437721111130198

BJÖRKQVIST, K.; ÖSTERMAN, K.; HJELT-BÄCK, M. (1994a) Aggression among university employees. Aggressive Behavior, n. 20, p. 173-184.

BJÖRKQVIST, K.; ÖSTERMAN, K.; LAGERSPETZ, K. (1994b) Sex differences in covert aggression in adults. Aggressive Behavior, n. 20, p. 27-33.

BOWEN, B.; PRIVITERA, M. R.; BOWIE, V. (2011) Reducing workplace violence by creating healthy workplace environments. Journal of Aggression, Conflict and Peace Research, v. 3, n. 4, p. 185-19, http://dx.doi.org/10.1108/17596591111187710 
BOWEN, P.; EDWARDS P.; LINGARD, H. (2013) Workplace stress among construction professionals in South Africa: The role of harassment and discrimination. Engineering, Construction and Architectural Management, v. 20, n. 6, p. 620-635, http://dx.doi.org/10.1108/ECAM-05-2012-0051

BOXMAN, E.; DEGRAAF, P.; FLAP, H. (1991) The impact of social and human capital on the income attainment of Dutch managers. Social Networks, v. 13, p. 5173.

BRADDOCK, J. H.; MCPARTLAND, J. (1987) How minorities coninue to be excluded from equal employment opportunities: research on a labor market an institutional barriers. Journal of Social Issues, v. 43, n. 1, p. 5-39.

BREWER, G.; WHITESIDE, E. (2012) Workplace bullying and stress within the prison service. Journal of Aggression, Conflict and Peace Research, v. 4, n. 2, p. 76-85, http://dx.doi.org/10.1108/17596591211208283

BROWN, B. J.; BAKER, S. (2007) Philosophies of Research into Higher Education. London, New York: Continuum International Publishing Group, p. 87-90. BRUDNIK-DABROWSKA, M. (2014) Mobbing in a Workplace Setting. Journal of Health Sciences, v. 4, n. 3, p. 369-381, http://dx.doi.org/10.5281/zenodo.17167 BUUNK, A. P.; FRANCO, S.; DIJKSTRA, P.; ZURRIAGA, R. (2016) Mobbing in Schools and Hospitals in Uruguay: Prevalence and Relation to Loss of Status. Journal of Interpersonal Violance, p. 1-12. DOI: $10.1177 / 0886260515625903$

CARNERO, M. A.; MARTINEZ, B.; SANCHEZ-MANGAS, R. (2012) Mobbing and workers' health: empirical analysis for Spain. International Journal of Manpower, v. 33, n. 3, p. 322-339, http://dx.doi.org/10.1108/01437721211234183

CETINTAS, K.; SARICAM, H. (2016) Self-esteem and perceived social competence: The preservative attempts to ostracism and loneliness for children. Conference: 1st Eurasian Congress on Positive Psychology, At Uskudar University, Istanbul. Prieiga per internetą: <https://www.academia.edu/24954603/Selfesteem_and_perceived_social_competence_The_preservative_attempts_to_ostracis m_and_loneliness_for_children> (prijungta 201606 20).

CHEUNG, H. K.; KING, E.; LINDSEY, A.; MEMBERE, A.; MARKELL H. M.; KILCULLEN, M. (2016) Understanding and Reducing Workplace Discrimination, in M. Ronald Buckley, Jonathon R. B. Halbesleben, Anthony R. Wheeler (ed.) Research in Personnel and Human Resources Management (Research in Personnel and Human Resources Management, Volume 34) Emerald Group Publishing Limited, p. 101-152.

ÇINAR, O.; KARCIOGLU, F. (2015) The Relationshio between Cyber Loafing and Organizational Citizenship Behavior: A Survey Study in Erzurum/Turkey. 11th International Strategic Management Conference 2015. Procedia - Social and Behavioral Sciences, n. 207, p. 444-453.

CULLEN, K. L.; FAN, J.; LIU, C. (2014). Employee Popularity Mediates the Relationship Between the Political Skill and Workplace Interpersonal Mistreatement. Journal of Management, v. 40, n. 6, p. 1760-1778. doi: 10.1177/0149206311435104.

DAVIS, W. D.; GARDNER, W. L. (2004) Perceptions of politics and organizational cynicism: An attributional and leader-member exchange perspective. The 
Leadership Quarterly, v. 15, n. 4, p. 439-465, http://dx.doi.org/10.1016/j.leaqua.2004.05.002

D'CRUZ, P.; NORONHA, E. (2011) The limits to workplace friendship: Managerialist HRM and bystander behaviour in the context of workplace bullying. Employee Relations, v. 33, n. 3, p. 269-288, http://dx.doi.org/10.1108/01425451111121777

DE BACKER, M.; BOEN, F.; DE CUYPER, B.; HOIGARD, R.; VANDE BROEK, G. (2015). A team fares well with a fair coach: Predictors of social loafing in interactive female sport teams. Scandinavian Journal of Medicine and Science of Sport, v. 25, n. 6, p. 897-908.

DIERGARTEN, E. (1994) Mobbing - Wenn der Arbeitsalltag zum Alptraum wird. Bund Verlag, Köln.

DRABEK, M.; MERECZ, D. (2013) Job stress, occupational position and gender as factors differentiating workplace bullying experience. Medycyna Pracy, v. 64, n. 3, p. 283-296.

DRENTEA, P. (1998) Consequencies of women's formal and informal job search methods for employent in female-dominated jobs. Gender and Society, v. 12, n. 3, p. 331-338.

EINARSEN, S.; SKOGSTAD, A. (1996) Bullying at work: Epidemiological findings in public and private organizations. European Journal of Work and Organizational Psycholgy: Mobbing and victimization at work, London, p. 185-201.

EINARSEN, S.; RAKNES, B. I. (1997) Harassment in the workplace and the victimization of men. Violence and Victims, v. 12, p. 247-263.

EROL, Y.; OZTOPRAK, M. T. (2015) The Mediating Role of Job Stress on The Effect of Mobbing on Burnout: An Analysis of Social Security Organization Employees in The District of Ankara. Journal of Business Research Turk, v. 7, n. 2, p. 87-114.

FERRIS, D. L.; BROWN, D. J.; BERRY, J. W.; LIAN, H. (2008) The Development and Validation of the Workplace Ostracism Scale. Journal of Applied Psychology, v. 93 , n. 6 , p. 1348-1366, DOI: 10.1037/a0012743

FOLEY, S.; NGO, H.; LOI, R.; ZHENG, X. (2015) Gender, gender identification and perceived gender discrimination: An examination of mediating processes in China. Equality, Diversity and Inclusion: An International Journal, v. 34, n. 8, p. 650665, http://dx.doi.org/10.1108/EDI-05-2015-0038

FU, I. P. (2015). Favoritism: Ethical Dilemmas Viewed Through Multiple Paradigms. The Journal of Values-Based Leadership, v. 8, n. 1, p. 1-7.

GAMIAN-WILK, M. (2013) Does Bullying Increase Compliance? Social Influence, v. 8, n. 2-3, p. 131-148, doi: 10.1080/15534510.2012.756429

GENERAL DIRECTORATE OF FAMILY AND COMMUNITY (2013) Turkey adolescent research profile-2013.

http://ailetoplum.aile.gov.tr/data/544f6ddd369dc328a057d01c/tepa2013_teksf.pdf. Accessed 12/05/2016.

GIORGI, G.; ARENAS, A.; LEON-PEREZ, J. M. (2011) An Operative Measure of Workplace Bullying: The Negative Acts Questionnaire Across Italian Companies. Industrial Health, n. 49, p. 686-695. 
GKOREZIS, P.; BELLOU, V. (2016) The relationship between workplace ostracism and information Exchange The mediating role of self-serving behavior. Management Decision, v. 54, n. 3, p. 700-713. http://dx.doi.org/10.1108/MD-09-2015-0421

GOK, S. (2011). Prevalence and types of mobbing behavior: A research on banking employees. International Journal of Human Sciences, v. 8, n. 1, p. 318-334.

GÖRZIG, A. (2016) Adolescents' Viewing of Suicide-Related Web Content and Psychological Problems: Differentiating the Roles of Cyberbullying Involvement. Cyberpsychology, Behavior, and Social Networking, v. 19, n. 8, p. 502-509. doi:10.1089/cyber.2015.0419.

GRANOVETTER, M. (1974) Getting a Job. 2nd edition. University of Chicago Press, Chicago, IL.

HITLAN, R. T.; KELLY, K. M.; SCHEPMAN, S.; SCHNEIDER, K. T.; ZARATE, M. A. (2006) Language Exclusion and consequences of perceived ostracism in the workplace. Group Dynamics-Theory Research and Practice, v. 10, n. 1, p. 56-70, DOI: 10.1037/1089-2699.10.1.56

HOEL, H.; EINARSEN, S.; COOPER, C. L. (2003) Organizational effects of bullying. Bullying and Emotional Abuse in the workplace: international perspectives in research and practice. London: Taylor and Francis.

HOLLIBAUGH, G. E. (2015) Naïve Cronyism and Neutral Competence: Patronage, Performance, and Policy Agreement in Executive Appointments. Journal of Public Administration Research and Theory, v. 25, p. 341-372.

HOLLIS, L. P. (2015) Bully University? The Cost of Workplace Bullying and Employee Disengagement in American Higher Education. Sage Open, v. 5, n. 2, DOI: $10.1177 / 2158244015589997$

HOLLIS, L. P. (2016) Labor Intensive: Workplace Bullying, Union Membership, and Unrealized Civil Rights for People of Color, in Leah P. Hollis (ed.) The Coercive Community College: Bullying and its Costly Impact on the Mission to Serve Underrepresented Populations (Diversity in Higher Education, Vo1.8) Emerald Group Publishing Limited, p. 83-101; DOI: 10.1108/S1479-364420160000018011

HRAST, M. F.; MRAK, A. K.; RAKAR, T. (2013) Social exclusion of elderly in Central and Eastern Europe. International Journal of Social Economics, v. 40, n. 11, p.971-989, http://dx.doi.org/10.1108//JSE-05-2012-0082

HUTCHINSON, M.; JACKSON, D. (2014) The construction and legitimation of workplace bullying in the public sector: Insight into power dynamics and organizational failures in health and social care. Nursing Inquiry, v. 22, p. 13-26.

I-PANG, F. (2015) Favoritism: Ethical Dilemmas Viewed Through Multiple Paradigms. The Journal of Values-Based Leadership, v. 8, n. 1, Article 6. Available at: http://scholar.valpo.edu/jvbl/vol8/iss1/6

JASKIEWICZ, P.; UHLENBRUCK, K.; BALKIN, D. B.; REAY, T. (2013) Is Nepotism Good or Bad? Types of Nepotism and Implications for Knowledge Management.

Family Business Review, v. 26, n. 2, p. 121-139.

JONSSON, P. O. (2001) Networks, culture, transaction costs and discrimination. International Journal of Social Economics, v. 28, n. 10/11/12, p. 942-958, http://dx.doi.org/10.1108/EUM0000000006134 
KANG, H. C.; KIM, J. (2016) Why do family firms switch between family CEOs and non-family professional CEO?: Evidence from Korean Chaebols. Review of Accounting and Finance, v. 15, n. 1, p. 45-64, http://dx.doi.org/10.1108/RAF-032015-0032

KARADAL, H.; SAYGIN, M. (2013) An Investigation of the Relationship between Social Loafing and Organizational Citizenship Behavior. Procedia - Social and Behavioral Sciences, n. 99, p. 206-215.

KARATUNA, I. (2015) Targets' coping with workplace bullying: a qualitative study. Qualitative Research in Organizations and Management: An International Journal, v. 10, n. 1, p. 21-37.

KELEŞ, H., N.; ÖZKAN, K.; BEZIRCI, M. (2011). A study on the effects of nepotism, favoritism and cronyism on organizational trust in the auditing process in family businesses in Turkey. International Business \& Economics Research Journal, n. 10, p. 9-16.

KERR, N. L.; SEOK, D. H.; POULSEN, J. R.; HARRIS, D. W.; MESSE, L. A. (2008) Social ostracism and group motivation gain. European Journal of Social Psychology, v. 38, p. 736-746.

KERSTENS, J.; VEENSTRA, S.; JAISHANKAR, K. (2015) Cyber Bullying in the Netherlands: A Criminological Perspective. International Journal of Cyber Cryminology, http://dx.doi.org/10.52

KNORZ, C.; ZAPF, D. (1995) Mobbing: Eine extreme Form sozialer Stressoren am Arbeitsplatz. Zeitschrift fuer Arbeits und Organisationspsychologie, n. 1, p. 1222.

KOSTEV K.; REX, J.; WAEHLERT, L.; HOG. D.; HEILMAIER, C. (2014) Risk of psichiatrik and neurological diseases in patients with workplace mobbing experience in Germany: a retrospective database analysis. Value in Health, v. 16, n. 7, DOI: $10.3205 / 000195$

KRAGH, S. U. (2012) The Anthropology of Nepotism: Social Distance and Reciprocity in Organizations in Developing Countries. International Journal of Cross Cultural Management, v. 12, n. 2, p. 247-265.

KULKARNI, M.; SOMMER, K. (2015) Language-Based Exclusion and Prosocial Behaviors in Organizations. Human Resource Management, v. 54, n. 4, p. 637652, DOI: $10.1002 / \mathrm{hrm} .21637$

LEUNG, A. S. M.; WU, L. Z.; CHEN, Y. Y.; YOUNG, M. N. (2011) The impact of workplace ostracism in the service organizations. International Journal of Hospitality Management, v. 30, n. 4, p. 836-844. DOI: 10.1016/j.ijhm.2011.01.004 LEYMANN, H. (1990) Mobbing and psychological terror at workplaces. Violence and Victims, v. 5, n. 2, p. 119-126.

LEYMANN, H. (1993) Mobbing: Psychoterror am Arbeitsplatz und wie man sich dagegen wehren kann. Reinbek bei Hamburg: Rowohlt Taschenbuch Verlag.

LEYMANN, H. (1995) Der neue Mobbing Bericht; Erfahrungen und Initiativen, Auswege und Hilfsangebote. Reinbek bei Hamburg: Rowohlt Taschenbuch Verlag. LEYMANN, H. (1996) The content and development of mobbing at work. European Journal of Work and Organizational Psychology, v. 5, n. 2, p. 165-184. 
LIDEN, R. C.; WAYNE, J. S.; JAWORSKI, R. A.; BENNET, N. (2004) Social Loafing: A Field of Investigation. Journal of Management, v. 30, n. 2, p. 285-304. http://dx.doi.org/10.1016/j.jm.2003.02.002

LIU, B.; LIU, J.; HU, J. (2010) Person-organization fit, job satisfaction, and turnover intention: an empirical study in the Chinese public sector. Social Behavior and Personality: An International Journal, v. 38, n. 5, p. 615-625.

MARTIN, B. (2000) Mobbing: Emotional Abuse in the American Workplace. Journal of Organizational Change Management, v. 13, n. 4, p. 401-446,

http://dx.doi.org/10.1108/jocm.2000.13.4.401.3

MATHISEN, G. E.; OGAARD, T.; EINARSEN, S. (2012) Individual and situatioi. 5, p. 539-555, http://dx.doi.org/10.1108/01437721211253182

MAVIN, S. (2008) Queen bees, wanabees and afraid to bees: no more best enemies for women in management. British Journal of Management, v. 19, n. 1, p. 165184.

MCKAY, R. B. (2014) Confronting Workplace Bullying: Agency and Structure in the Royal Canadian Mounted Police. Administration and Society, v. 46, n. 5, p. 548572.

MEFOK, P. C.; NWANOSIKE, C. L. (2012) Effects of Group Size and Expectancy of Reward of Social Loafing. Journals of Africa Online, v. 20, n. 1.

MESSARRA, L. C.; KARKOULIAN, S.; MCCARTHY, R. (2011) To restrict or not to restrict personal internet usage on the job. Education, Business and Society:

Contemporary Middle Eastern Issues, v. 4, n. 4, p. 253-266,

http://dx.doi.org/10.1108/17537981111190042

MOK, A.; De CREMER, D. (2016) The bonding effect of money in the workplace:priming money weakens the negative reationship between relationship between ostracism and prosocial behaviour. European Journal of Work and Organizational Psychology, v. 25, n. 2, p. 272-286.

http://dx.doi.org/10.1080/1359432X.2015.1051038

MULDER, R.; BOS, E.; POUWELSE, M.; VAN DAM, K. (2016) Workplace mobbing: How the victim's coping behavior influences bystander responses. Journal of Social Psychology, v. 17, p. 1-14.

MUTLU, K. (2000) Problems of nepotism and favouritism in the police organization in Turkey. Policing: An International Journal of Police Strategies \& Management, v. 23, n. 3, p. 381-389. http://dx.doi.org/10.1108/13639510010343056

NADEEM, M.; AHMAD, R.; AHMAD, N.; BATOOL, S. R.; SHAFIQUE, N. (2015) Favoritism, nepotism And cronyism as predictors of job satisfaction: Evidences from Pakistan. Journal of Business and Management Research, v. 8, p. 224-228.

NAUS, F.; VAN ITERSON, A.; ROE, R. (2007) Value incongruence, Job autonomy, and organization-Based Self-esteem: a Self-Based Perspective on organizational cynicism. European Journal of Work and Organizational Psychology, v. 16, n. 2, p. 195-219, DOI: 10.1080/13594320601143271.I

NEUBERGER, O. (1994) Mobbing: Übel mitspielen in Organisationen. München: Rainer Hampp Verlag. 
NEZLEK, J. B.; WESSELMANN, E. D.; WHEELER, L.; \& WILLIAMS, K. D. (2012) Ostracism in everyday life. Group Dynamics: Theory, Research, and Practice, $v$. 16, p. 91-104.

NIEDL, K. (1995) Mobbing/Bullying am Arbeitzplatz. Eine Empirische Analyse zum Phaenomen sowie zu personalwirtschaftlich relevanten Effekten von systematischen Feindseligkeiten. Personalwirtschaftliche Schriften, Muenchen, Mering: Rainer Hampp Verlag.

OGURLU, U. (2015) Ostracism among Gifted Adolescents: A Preliminary Study inTurkey. Educational Process: International Journal, v. 4, n. 1-2, p. 18-30, http://dx.doi.org/10.12973/edupij.2015.412.2

ONOSHCHENKO, O.; WILLIAMS, C. (2014) Evaluating the role of blat in finding graduate employment in post-Soviet Ukraine: The "dark side" of job recruitment? Employee Relations, v. 36, n. 3, p. 254-265, http://dx.doi.org/10.1108/ER-06-20130070

O'REILLY, J., ROBINSON, S., L., BERDAHL, J., BANKI, S. (2014) Is Negative Attention Better Than No Attention? The Comparative Effects of Ostracism and Harassment at Work. Organization Science, v. 26, n. 3, p. 774-793. http://dx.doi.org/10.1287/orsc.2014.0900

OZLER, N. D. E.; BUYUKARSLAN, B. A. (2011) The Overall Outlook Of Favoritism In Organizations: A Literature Revie. International Journal Of Business And Management Studies, v. 3, n. 1, p. 275-284.

PADGETT, M. Y.; MORRIS, K. A. (2005) Keeping it "All in the family:" Does nepotism in the hiring process really benefit the beneficiary? Journal of Leadership \& Organizational Studies, v. 11, n. 2, p. 34-45.

PALIDAUSKAITÉ, J. (2011) Ethical Problems in Public Life and Their Solution: Lithuanian Scenario. Social Sciences, v. 71, n. 1, p. 15-23.

PETERSON, J. S.; RAY, K. E. (2006) Bullying and the gifted: Victims, perpetrators, prevalence, and effects. Gifted Child Quarterly, n. 50, p. 148-168.

PILCH, I.; TURSKA, E. (2015) Relationships Between Machiavellianism,

Organizational Culture, and Workplace Bullying: Emotional Abuse from the Target's and the Perpetrator's Perspective. Journal of Business Ethics, v. 128, 1, p. 83-93.

PILIPONYTĖ, J. (2004). Korupcija: teoriniai bandymai apibrèžti ir paaiškinti.

Sociologija. Mintis ir veiksmas, n. 2. p. 83-95.

PIVORAS, S. (2012). Konkursinès atrankos i Lietuvos valstybès tarnybą tobulinimas gero valdymo iššūkių perspektyvoje. Viešoji politika ir administravimas, v. 11, n. 3. p. 473-487.

PONZO, M.; SCOPPA, V.(2010) The use of informal networks in Italy: Efficiency or favoritism? Journal of Socio-Economics, v. 39, n. 1, p. 89-99.

POON, K.; CHEN, Z. (2014) When justice surrenders: The effect of just-world beliefs on aggression following ostracism. Journal of Experimental Psychology, v. 52, p. 101-122. doi:10.1016/j.jesp.2014.01.006

PRUSKUS, V. (2003). Verslo etika. Vilnius: Enciklopedija.

PUČĖTAITE், R. (2016) Žmogiškuju ištekliụ valdymo vadybos etinès problemos kultūros organizacijoje. Meno vadyba, Vilnius: VU, sudarytoja V. Jurènienė. 
PUČĖTAITĖ, R.; LAMSA, A. M. (2008) Developing Organizational Trust Through Advancement of Employees' Work Ethic in a Post-Socialist Context. Journal of Business Ethics, v. 82, n. 2, p. 325-337, DOI: 10.1007/s10551-008-9922-X

PUČĖTAITÉ, R.; LAMSA, A. M.; NOVELSKAITE், A. (2010) Building organizational trust in a lowtrust societal context. Baltic Journal of Management, v. 5, n. 2, p. 197217, http://dx.doi.org/10.1108/17465261011045124

QUINE, L. (1999) Workplace bullying in NHS community trust: staff questionnairw survey. British Medical Journal, p. 228-232.

QURESHI, M. I.; RASLI, A. M.; ZAMAN, K. (2014) A New Trilogy to Understand the Relationship among Organizational Climate, Workplace Bullying and Employee Health. ARAB Business and Economics Journal, v. 9, p. 133-146.

RALYS, K. (2010) Šeima kaip vertybè katalikų, tikèjimo, amžiaus ir lyties aspektu. Ugdymo psichologija. n. 21.

RAYNER, C.; HOEL, H. (1997) A summary review of literature relating to workplace bullying. Journal of Community and Applied Social Psychology, n. 7, p. 181191.

RECARIO, R. N.; ROBLES M. B. B.; BAUTISTA K. E. P.; PABICO J. P. (2015)

Social Loafing Among Undergraduate Software Engineering Groups: Persistence of Perception Seven Years After. 13th National Conference on Information Technology Education (NCITE 2015), Angeles University Foundation, Angeles City, Pampanga, Philippines, 22-24 October 2015.

RENN, R.; ALLEN, D.; HUNUNG, T. (2013) The Relationship of Social Exclusion at Work With Self-defeating Behavior andTurnover. Journal of Social Psychology, v. 153 , n. 2, p. 229-249, DOI: 10.10280/00224545.2012.723642

RICHARDS, J. (2012) Examining the exclusion of employees with Asperger syndrome from the workplace. Personnel Review, v. 41, n. 5, p. 630-646, http://dx.doi.org/10.1108/00483481211249148

ROSENBAUM, M. S.; WALSH, G.; WOZNIAK, R. (2012) Family allowances as reverse retail discrimination. International Journal of Retail \& Distribution Management, v. 40, n. 5, p. 342-359, http://dx.doi.org/10.1108/09590551211222321 RUGGIERI, S., BENDIXEN, M., GABRIEL, U., ALSAKER, F. (2013) Do Victimization Experiences Accentuate Reactions to Ostracism? An Experiment Using Cyberball. International Journal of Developmental Science, v. 7, p. 25-32.

SAFINA, D. (2015) Favouritism and Nepotism in an Organization: Causes and Effects. Procedia - Economics and Finance, v. 23, p. 630-634. doi:10.1016/S2212-5671(15)00416-5

SALIN, D. (2003) Ways of Explaining Workplace Bullying: A Review of Enabling, Motivating and Precipitating Structures and Processes in the Work Environment. Human Relashions, v. 56, n. 10, p. 1213-1232.

SALIN, D. (2005) Workplace Bullying among Business Professionals: Prevalence, Gender Differences and the Role of Organizational Politics. Perspectives interdisciplinaires sur le travail et la santé [En ligne], 7-3. URL: http://pistes.revues.org/3159 
SARPONG, D.; MACLEAN, M. (2015) Service nepotism in the multi-ethnic marketplace: mentalities and motivations. International Marketing Review, v. 32, n. 2, p.160 - 180. http://dx.doi.org/10.1108/IMR-01-2014-0030

SCHAUFELI, W. B.; SALANOVA, M. (2011) Work engagement: on how to better catch a slippery concept. European Journal of Work and Organizational Psychology, v. 20, p. 39-46.

SCOTT, A. K.; ZWEIG, D. (2016) Understanding and mitigating cynicism in the workplace. Journal of Managerial Psychology, v. 31, n. 2, p. 552-569, http://dx.doi.org/10.1108/JMP-01-2015-0023

SCOTT, K. L.; DUFFY, M. K. (2015) Antecedents of Workplace Ostracism: New Directions in Research and Intervention, in Pamela L. Perrewé, Jonathon R. B. Halbesleben, Christopher C. Rosen (ed.) Mistreatment in Organizations (Research in Occupational Stress and Well-being, Volume 13) Emerald Group Publishing Limited, p.137-165; doi: 10.1108/S1479-355520150000013005

SCOTT, K. L.; ZAGENCZYNK, T. J.; SCHIPPERS, M.; PURVIS, R. L.; CUZ, K. S. (2014) Co-worker Exclusion and Employee Outcomes: An Investigation of the Moderating Roles of Perceived Organizational and Social Support. Journal of Management Studies, v. 51, n. 8, p. 1235-1256.

SEALEY, C. (2015) Social exclusion: re-examining its conceptual relevance to tackling inequality and social injustice. International Journal of Sociology and Social Policy, v. 35, n. 9-10, p. 600-617, http://dx.doi.org/10.1108/lJSSP-05-20140040

SHAPIRO, J.; P.; STEFKOVICH, J.; A. (2011) Ethical leadership and decisionmaking in education. Applying theorical perpectives to complex dilemas (3rd edition). New Your, Routledge.

SHEPHERD, C. D.; TASHCHIAN, A.; RIDNOUR, E. R. (2011) An investigation of the job burnout sindrome in personal selling. Journal of Personal Selling \& Sales Management, v. 31, n. 4, p. 397-409.

SIMHA, A.; ELLOY, D. F.; HUANH, H. C. (2014) The moderated relationship between job burnout and organizational cynicism. Management Decision, v. 52, n. 3, p. 482-504, http://dx.doi.org/10.1108/MD-08-2013-0422

SULLIVAN, T. N.; FARRELL, A. D.; KLIEWER, W. (2006) Peer victimisation in early adolescence: Association between physical and relational victimisation and drug use, aggression, and delinquent behaviors among urban middle school students. Development and Psychopathology, n. 18, p. 119-137.

TAMBULASI, R. I. C. (2009) Pushed to the abyss of exclusion: ICT and social exclusion in developing countries. Journal of Information, Communication and Ethics in Society, v. 7, n. 2-3, p. 119-127, http://dx.doi.org/10.1108/14779960910955837

TATA, J. (2002) THE INFLUENCE OF ACCOUNTS ON PERCEIVED SOCIAL LOAFING IN WORK TEAMS. International Journal of Conflict Management, v. 13, n. 3, p. 292-308, http://dx.doi.org/10.1108/eb022878

TEKINER, M. A.; TAVAS, B. (2016) Analysis of organizational cynicism and organizational loyalty: Turkish Police Department Sample. Journal of Human Sciences, v. 13, n. 1, p. 2338-2348, http://dx.doi.org/10.14687/ijhs.v13i1.3751 
THAU, S.; DERFLER-ROZIN, R.; PITESA, M.; MITCHELL, M. S.; PILLUTLA, M. M. (2015) Unethical for the Sake of the Group: Risk of Social Exclusion and Pro-Group Unethical Behavior. Journal of Applied Psychology, v. 100, n. 1, p. 98-113, DOI: 10.1037/a0036708.

TOGONZ N.; YILMAZ G. H. (2008) Organizational Cynicism: an linvestigation on Hotel Organizatinions in ESKISEHIR and ALANYA, Anadolu Üniversitesi sosyal bilimler dergisi. Anadolu University journal of social sciences, v. 8, n. 2, p. 283305.

TREVINO, L. K.; NELSON K. A. (2004) Managing Business Ethics. 3rd edition, New York, John Willey and Sons, Inc.

VAN DER WALT, F.; MPHOLO, T. S.; JONCK, P. (2016) Perceived religious discrimination as predictor of work engagement, with specific reference to the Rastafari religijon. Verbum et Ecclesia, v. 37, n. 1, p. 1-9.

http://dx.doi.org/10.4102/ve.v37i1.1524

VAN DICK, R.; TISSINGTON, P. A.; Hertel, G. (2009) Do many hands make light work?: How to overcome social loafing and gain motivation in work teams.

European Business Review, v. 21 n. 3, p. 233-245, http://dx.doi.org/10.1108/09555340910956621

VARTIA-VAANANEN, M. (1996) The sources of bullying - psychological work: enviroment and organizational climate. European Journal of Work and Organizational Psychology: Mobbing and victimization at work. London, p. 203215.

VASCONCELOS, A. F. (2015) Portraying some determinants of discrimination in the workplace. Management Research: The Journal of the Iberoamerican Academy of Management, v. 13, n. 2, p. 211-232, http://dx.doi.org/10.1108/MRJIAM-02-20150574

VASILJEVIENĖ, N. (2006) Organizacijụ etika: instucinės etikos vadybos sistemos. Vilnius: VU, Jungtinis Verslo etikos centras.

VASILJEVIENĖ, N.; PUČĖTAITĖ, R. (2009) Establishing integrity to eliminate women discrimination in science: implications from empirical research in Lithuania, Economics and Management, n. 14, p. 633-640.

VEGA, G.; COMER, D. (2005) Sticks and stones may break you bones, but words can break your spirit: Bullying in the workplace. Journal of Business Ethics, v. 58, p. 101-109.

VĖTAITĖ, I.; KOLČINIENĖ A.; MACAS, A.; MIKALAUSKAS A.; BILSKIENE், D. (2010) Stresas ir nuovargis medico darbe:gydytojų anesteziologų-renimatologų patirtis. Available: https://ojs.kauko.It/index.php/ssktpd/article/viewFile/77/71. Access 28/07/2016.

VICKERS, M. H. (2009) Bullying, disability and work: a case study of workplace bullying. Qualitative Research in Organizations and Management: An International Journal, v. 4, n. 3, p. 255-272.

VICKERY, W. L. (2013). Producing and Scrounging During Problem Based Learning. Journal of Problem Based Learning in Higher Education, v. 1, n. 1, p. 36-52, http://dx.doi.org/10.5278/ojs.jpblhe.v1i1.272 
VON HIPPEL, C. D. (2006) When people would rather switch than fight: out-group favoritism among temporary employees. Group Processes \& Intergroup Relations, v. 9, p. 533-546.

VOSYLIŪTĖ, A. (2010) Moterys: vienišumo reikšmès. Gender Studies \& Research, n. 8.; p. 109-115.

VVEINHARDT, J. (2012a) Identification of the Reliability of Methodological Characteristics of Quality in the Diagnostic Instrument for Mobbing as Discrimination in Employee Relations on Purpose to Improve the Climate in Lithuanian Organisations. Transformations in Business and Economics, v. 11, n. 2(26), p. 218-232.

VVEINHARDT, J. (2012b) Nepotizmo vertinimo dichotomija: socialinès ir etinès dimensijos. Organizaciju vadyba: sisteminiai tyrimai, n. 64, p. 123-134, http://dx.doi.org/10.7220/MOSR.1392.1142.2012.64.8

VVEINHARDT, J. (2016) Employees' Safety from Psychological Violence in Social Enterprises: State Subsidies or Private Initiative? Social Enterprise - ContextDependent Dynamics In A Global Perspective, edited by Rosario Laratta, ISBN 978-953-51-2275-3, doi: 10.5772/62474 p. 105-125.

VVEINHARDT, J.; PETRAUSKAITÉ, L. (2013) Nepotizmo, favoritizmo ir protekcionizmo trianguliacijos koncepcinis modelis. Organizaciju vadyba: sisteminiai tyrimai, n. 65, p. 137-148, http://dx.doi.org/10.7220/mOSR.1392.1142.2013.65.10

VVEINHARDT, J.; ŽUKAUSKAS, P.; RIVERA, M. (2014) Testing Hypotheses Concerning Correlations between "Mobbing as Discrimination" Employee Relations and Organizational Climate. Problems and Perspectives in Management, v. 12, n. 3, p. 26-37.

VVEINHARDT, J.; ZYGMANTAITÉ, R. (2015) Influence of CSR Policies in Preventing Dysfunctional Behaviour in Organizations. Procedia - Social and Behavioral Sciences, v. 205, p. 340-348. doi:10.1016/j.sbspro.2015.09.095

WILKERSON J. M.; EVANS W. R.; DAVIS W. D. (2008) A test of coworkers' influence on organizational cynicism, badmouthing, and organizational citizenship behavior. Journal of Applied Social Psychology, v. 38 n. 9, p. 2273-2292.

WILLIAMS, E. S.; LAWRENCE, E. R.; CAMPBELL, K. S.; SPIEHLER, S. (2009) The effect of emotional exhaustion and depersonalization on physician-patient communication: A theoretical model, implications, and directions for future research, in Grant T. Savage, Myron D. Fottler (ed.) Biennial Review of Health Care Management: Meso Perspective (Advances in Health Care Management, Volume 8) Emerald Group Publishing Limited, p. 3-20, doi: 10.1108/S14748231(2009)0000008005

WILLIAMS, K.; HARKINS, S.; LATANE, B. (1981) Identifiability as a deterrent to social loafing: two cheering experiments. Journal of Personality and Social Psychology, v. 40, n. 2, p. 303-311.

WU, CH.; LIU, J.; KWAN, H.; LEE, C. (2016) Why and When Workplace Ostracism Inhibits Organizational Citizenship Behaviors: An Organizational Identification Perspektive. Journal of Applied Psychology, v. 101, n. 3, p. 362-378. 
YAN, Y.; ZHOU, E. H.; LONG, L. R.; JI, Y. (2014) The Influence of Workplace Ostracism on Counterproductive Work Behavior: The Mediating Effect of State Selfcontrol. Social Behavior and Personality, v. 42, n. 6, p. 881-890. DOI: 10.2224/sbp.2014.42.56.881

YANGA, M. L.; AMOAKO, I. O. (2013) Legitimizing Dishonesty in Organizations: A Survey of Managers in Four Sub-Sahara African Countries, in Tiia Vissak, Maaja Vadi (ed.) (Dis)Honesty in Management (Advanced Series in Management, Volume 10) Emerald Group Publishing Limited, p. 243-268, DOI: 10.1108/S18776361(2013)0000010015

YILDIZ, B.; LUTFIHAK, A. (2015) A Theoretical Model on the Proposed Predictors of Destructive Deviant Workplace Behaviors and the Mediator Role of Alienation.

Procedia - Social and Behavioral Sciences, v. 210, p. 330-338. DOI:

10.1016/j.sbspro.2015.11.373

YILDIZ, S.; ŞAYLIKAY, M. (2014) The Effect of Organizational Cynicism on Alienantion. Procedia - Social and Behavioral Sciences, v. 108, p. 622-627, DOI: 10.1016/j.sbspro.2013.12.517

ZHAO, H.; PENG, Z.; SHEARD, G. (2013) Workplace ostracism and hospitality employees' counterproductive work behaviors: The joint moderating effects of proactive personality and political skill. International Journal of Hospitality Management, v. 33, p. 219-227. doi: 10.1016/j.ijhm.2012.08.006

ZIGMAN, O. (2014) Romanian Social Care Workers' Exposure to Workplace Violance. Cross-Cultural Management Journal, v. 16, n. 1(5), p. 223-232.

ZIMMERMAN, C. A.; CARTEER-SOWELL, A. R.; XU, X. H. (2016) Examining Workplace Ostracism Experiences in Academia: Understanding How Differences in the Faculty Ranks Influence Inclusive Climates on Campus. Frontiers in Pshychology, v. 7, n. 753. http://dx.doi.org/10.3389/fpsyg.2016.00753

ŽUKAUSKAS, P.; VVEINHARDT, J. (2013) Vadybinès transformacijos socialiai darniai visuomenei ir konkurencingai valstybei plètoti: organizacijos klimato krizę sukeliančių reiškinių diagnostika. Vytauto Didžiojo universiteto mokslo klasteriai, p. 273-282.

ŽUKAUSKAS, P.; VVEINHARDT, J. (2015) Diagnosis of mobbing as discrimination in employee relations. Engineering Econimics, v. 64, n. 4, p. 103-113.

ŽULOVA, J. (2015) Legal Issues Associated with Nepotism in the Workplaces in the Slovak Republic. European Scientific Journal, v. 1, p. 10-17.

ZUSCHLAG, B. (1994) Mobbing: Schikane am Arbeitzplatz. Goettingen: Verlag fuer angewandte Psychologie. 